\title{
Physiological Basis of Screening Rice Varieties for Low Temperature Stress Tolerance
}

\author{
Anderson Amalan Kumar ${ }^{1 *}$ and K. Krishna Surendar ${ }^{2}$ \\ ${ }^{1}$ Department of Crop Physiology, AC \& RI, TNAU, Kudumiyanmalai, India \\ ${ }^{2}$ Department of Crop Physiology, AC \& RI, TNAU, Coimbatore, India \\ *Corresponding author
}

\begin{tabular}{|l|}
\hline Ke y w o r d s \\
Rice, Low \\
temperature, \\
Morphological, \\
Physiological and \\
yield
\end{tabular}

A B S T R A C T
A field experiment was conducted at the Regional Research Station, Paiyur main farm with the varieties viz., ADT 38, ADT 39, ADT 43, Anna 4, Bhavani, BPT 5204, CO43, IR 20, IR 42, IR 50, K 429, Karuppunel, Kottanel, MDU 3, MDU 4, MDU 5, Paiyur 1, PS 1, PS 2,PS 3, Savulu samba and White Ponni The experiment was designed for screening the rice cultivars for low temperature stress tolerance through the physiological and biochemical responses. The experiment was laid out in RBD with three replications and twenty two varieties. The rice seedlings were transplanted in the main field with the spacing of $22.5 \times 22.5 \mathrm{~cm}$ during late sampa season (October 2014). The results of experiment explained that maximum plant height was observed in Kottanel and Doddabayarunel and root length was maximum in ADT 38 and was followed by Paiyur 1 and Bhavani at $0^{\text {th }}$ DAT. At 30 DAT maximum plant height was observed in Kottanel. Root length was maximum in BPT 5204 maximum number of tillers was observed in ADT 38 and was followed by IR 20 which recorded highest number of leaves per plant. At 60 DAT, maximum plant height was observed in Karuppunel. Root length was maximum in Bhavaniand maximum number of tillers was observed in IR 20.Anna 4 which recorded highest number of leaves per plant. At 90 DAT, maximum plant height was observed in DBN. Root length was maximum in White ponniand maximum number of tillers was observed in PS 3.Maximum grain yield $\mathrm{ha}^{-1}$ was recorded in the variety MDU 3 and was closely followed by MDU 4 and CO 43 and were on par with each other.

\section{Introduction}

Rice (Oryza sativa L.) is an important food crop of India. The cultivated rice originated in the South East Asia. Rice is the most important cereal crop because of its use as prime food in many countries of world. Rice is mainly grown during kharif but in some areas it is also grown during rabi. Rabi paddy is usually sown in the month of November to January that coincides with winter season in North India, and the cold adversely affect the rabi rice germination, growth at seedling stages, tillers formation and fertility and ultimately affecting yield. Rice plants are susceptible to low temperature during the 
young microspore primordial stage, which occurs 10-12 days before heading. Low temperature during seedling and vegetative growth stage of rice crop affects germination, formation of seedling, plantlet chlorosis, mortality and prolongs the duration of the crop and it effects the transplanting of subsequent autumn rice crop. Research findings shows that critical low temperatures can be damage germination to maturity stage. The critical temperature for rice is usually below $20^{\circ} \mathrm{C}$ and varies according to growth stage, for example, for germination, the critical temperature is $10^{\circ} \mathrm{C}$ and for the reproductive stage, it is $17^{\circ} \mathrm{C}$ (Li et al., 2011; Mackill and Lei, 1997). A plant can endure through two types of injuries after low temperature exposure. Chilling injury occurs due to lower temperature just above freezing point of water.

This phenomenon remains reversible initially but ultimately causes cell death due to prolonged cold spell. Sometimes the progressive colder temperature beyond critical range may result in hardening and/or acclimatization of plants which can lessen and/or abolish stress injury. Freezing injury is induced by the low temperature below freezing point. The intracellular freezing becomes fatal for the protoplasmic structure when the ice crystals grow large enough to disrupt the cells. In extra cellular freezing, the protoplasm of the plant becomes dehydrated because a water vapour deficit is created as cellular water is transferred to ice crystals formed in the intercellular spaces. Rice crop is more commonly abused by the chilling injury.

Thus, this experiment was designed for screening the rice cultivars for low temperature stress tolerance through the physiological and biochemical responses. Plant height, root length, number of tillers, Crop growth rate and relative growth rate, disintegration of cellular membranes and response of photosynthetic pigments will be taken in to consideration to assess the response of the various rice cultivars to low temperature condition from this experiment.

\section{Materials and Methods}

A field experiment was conducted at the RRS main farm with the varieties viz., ADT 38, ADT 39, ADT 43, Anna 4, Bhavani, BPT 5204, CO43, IR 20, IR 42, IR 50, K 429, Karuppunel, Kottanel, MDU 3, MDU 4, MDU 5, Paiyur 1, PS 1, PS 2,PS 3, Savulu samba and White Ponni with three replications were laid out in Randomized Block Design. The experiment was designed for screening the rice cultivars for low temperature stress tolerance through the physiological and biochemical responses.

The rice seedlings were transplanted in the main field with the spacing of $22.5 \times 22.5 \mathrm{~cm}$ during late sampa season (October 2014). Morphological characters like plant height, root length, number of tillers and number of leaves were recorded at 0, 30, 60 and 90 DAT (Days After Transplanting). The growth attributes characters viz., Crop Growth Rate (CGR) and Relative Growth Rate (RGR) were measured at 0-90 DAT. The straw and grain yield $\mathrm{ha}^{-1}$ was assessed at the time of harvesting.

\section{Results and Discussion}

Plants require an optimal temperature range for their growth, development and ultimate survival45. Low temperature has a strong impact on growth, survival, reproduction and distribution of plants. The seedlings get severely damaged by cold stress when they are grown in winter environments (Nishiyama, 1985).

In this present study, morphological observations were recorded at 0, 30, 60 and 90 DAT. At 0 DAT, significant difference was 
observed among varieties for plant height and root length. Maximum plant height $(26.0 \mathrm{~cm})$ was observed in Kottanel and Doddabayarunel. Root length was maximum in ADT $38(6.6 \mathrm{~cm})$ and was followed by Paiyur 1 and Bhavani $(5.7 \mathrm{~cm})$ (Table 1).

Rice is still a tropical C3 crop, which yields best under warm temperatures and high solar radiation (Karki et al., 2013). It is been reported to be more sensitive to cold stress than any other cereal crops, especially during seedling, tillering, panicle development and flowering stages (Mukhopadhyay et al., 2004).

The critical temperature for rice growth diverges with different developmental phases such as $10^{\circ} \mathrm{C}$ for germination and $17^{\circ} \mathrm{C}$ for the reproductive stages.

Table.1 Effect of low temperature stress on plant height, root length, number of tillers and number of leaves and yield of rice entries at different stages

\begin{tabular}{|c|c|c|c|c|c|c|}
\hline \multirow[b]{2}{*}{ Variety } & \multicolumn{2}{|c|}{ O DAT } & \multicolumn{4}{|c|}{30 DAT } \\
\hline & $\begin{array}{l}\text { Plant } \\
\text { height } \\
(\mathrm{cm})\end{array}$ & $\begin{array}{l}\text { Root length } \\
\qquad \text { (cm) }\end{array}$ & $\begin{array}{l}\text { Plant } \\
\text { height } \\
(\mathrm{cm})\end{array}$ & $\begin{array}{l}\text { Root } \\
\text { length } \\
(\mathrm{cm})\end{array}$ & $\begin{array}{c}\text { No. of } \\
\text { tillers / } \\
\text { plant }\end{array}$ & $\begin{array}{c}\text { No. of } \\
\text { leaves } / \\
\text { plant }\end{array}$ \\
\hline ADT 38 & 22.2 & 6.6 & 48.0 & 22.7 & 11.7 & 31.7 \\
\hline ADT 39 & 19.4 & 3.3 & 49.3 & 15.0 & 10.0 & 32.7 \\
\hline ADT 43 & 12.8 & 3.5 & 45.3 & 18.3 & 7.0 & 24.0 \\
\hline Anna 4 & 17.8 & 3.0 & 56.0 & 16.0 & 8.0 & 25.7 \\
\hline Bhavani & 23.9 & 5.7 & 46.0 & 15.3 & 7.7 & 22.7 \\
\hline BPT 5204 & 16.1 & 4.0 & 55.3 & 23.0 & 7.7 & 25.3 \\
\hline CO 43 & 14.4 & 3.8 & 44.3 & 16.0 & 8.3 & 28.0 \\
\hline IR 20 & 17.8 & 2.8 & 50.7 & 16.0 & 10.7 & 35.0 \\
\hline DBN & 26.0 & 3.7 & 60.7 & 15.3 & 7.3 & 26.7 \\
\hline IR 50 & 19.3 & 3.2 & 45.3 & 16.7 & 9.7 & 30.0 \\
\hline K 429 & 23.5 & 4.1 & 49.7 & 17.7 & 8.0 & 29.3 \\
\hline Karuppunel & 23.4 & 2.5 & 54.3 & 10.3 & 5.7 & 23.0 \\
\hline Kottanel & 26.0 & 4.8 & 63.0 & 13.3 & 9.0 & 29.0 \\
\hline MDU 3 & 15.0 & 4.1 & 44.0 & 14.3 & 6.3 & 25.3 \\
\hline MDU 4 & 16.8 & 3.8 & 51.7 & 19.0 & 5.0 & 19.3 \\
\hline MDU 5 & 15.6 & 3.4 & 42.7 & 12.7 & 6.7 & 24.0 \\
\hline Paiyur 1 & 19.0 & 5.7 & 44.0 & 13.3 & 8.0 & 24.7 \\
\hline PS 1 & 20.6 & 3.8 & 50.0 & 18.0 & 6.7 & 21.0 \\
\hline PS 2 & 17.5 & 2.7 & 53.7 & 19.0 & 8.7 & 27.7 \\
\hline PS 3 & 23.4 & 3.5 & 53.0 & 17.3 & 8.7 & 17.7 \\
\hline Savulu samba & 21.0 & 3.0 & 62.7 & 17.7 & 9.7 & 32.3 \\
\hline White Ponni & 19.6 & 4.7 & 50.3 & 9.0 & 9.0 & 24.7 \\
\hline SE (d) & 1.4 & 0.2 & 4.2 & 1.0 & 0.4 & 2.4 \\
\hline CD 0.05 & 2.8 & 0.4 & 8.4 & 2.1 & 0.8 & 4.9 \\
\hline
\end{tabular}


Table.2 Effect of low temperature stress on plant height, root length, number of tillers and number of leaves and yield of rice entries at different stages

\begin{tabular}{|c|c|c|c|c|c|c|c|c|}
\hline \multirow[b]{2}{*}{ Variety } & \multicolumn{4}{|c|}{60 DAT } & \multicolumn{4}{|c|}{90 DAT } \\
\hline & $\begin{array}{l}\text { Plant } \\
\text { height } \\
(\mathrm{cm})\end{array}$ & $\begin{array}{l}\text { Root } \\
\text { length } \\
(\mathrm{cm})\end{array}$ & $\begin{array}{c}\text { No. of } \\
\text { tillers / } \\
\text { plant }\end{array}$ & $\begin{array}{c}\text { No. of } \\
\text { leaves / } \\
\text { plant }\end{array}$ & $\begin{array}{l}\text { Plant } \\
\text { height } \\
(\mathrm{cm})\end{array}$ & $\begin{array}{l}\text { Root } \\
\text { length } \\
(\mathrm{cm})\end{array}$ & $\begin{array}{c}\text { No. of } \\
\text { tillers / } \\
\text { plant }\end{array}$ & $\begin{array}{c}\text { No. of } \\
\text { panicles / } \\
\text { plant }\end{array}$ \\
\hline ADT 38 & 58.3 & 13.0 & 7.0 & 27.0 & 71.3 & 16.0 & 7.0 & 7.0 \\
\hline ADT 39 & 63.7 & 11.3 & 10.3 & 35.0 & 69.3 & 13.0 & 12.3 & 10.0 \\
\hline ADT 43 & 50.0 & 12.0 & 9.0 & 22.7 & 77.7 & 12.0 & 7.0 & 7.0 \\
\hline Anna 4 & 70.0 & 15.7 & 15.0 & 49.0 & 60.7 & 8.0 & 10.0 & 8.3 \\
\hline Bhavani & 62.0 & 20.0 & 11.3 & 44.7 & 90.7 & 14.0 & 7.0 & 7.0 \\
\hline BPT 5204 & 60.3 & 13.0 & 6.0 & 18.0 & 64.0 & 10.3 & 10.0 & 8.0 \\
\hline CO 43 & 61.0 & 17.0 & 8.0 & 36.7 & 89.3 & 8.0 & 7.3 & 7.0 \\
\hline IR 20 & 56.3 & 12.0 & 16.0 & 45.0 & 77.0 & 16.0 & 12.0 & 7.3 \\
\hline DBN & 96.0 & 10.3 & 8.0 & 29.7 & 110.0 & 13.0 & 10.0 & 9.0 \\
\hline IR 50 & 59.0 & 16.0 & 9.3 & 33.0 & 60.0 & 10.3 & 12.3 & 8.0 \\
\hline K 429 & 68.0 & 14.0 & 8.0 & 36.0 & 89.0 & 11.0 & 11.0 & 11.0 \\
\hline Karuppunel & 106.0 & 8.0 & 8.0 & 26.0 & 90.3 & 9.0 & 9.7 & 8.0 \\
\hline Kottanel & 99.3 & 7.0 & 7.0 & 21.3 & 94.0 & 12.7 & 9.0 & 7.0 \\
\hline MDU 3 & 66.0 & 10.3 & 11.0 & 39.0 & 90.0 & 13.3 & 14.0 & 14.0 \\
\hline MDU 4 & 63.0 & 14.0 & 11.7 & 46.3 & 84.7 & 14.3 & 8.3 & 8.0 \\
\hline MDU 5 & 60.3 & 15.0 & 8.0 & 34.3 & 62.7 & 11.0 & 9.0 & 9.0 \\
\hline Paiyur 1 & 47.0 & 15.0 & 6.0 & 29.3 & 65.0 & 11.0 & 9.0 & 7.3 \\
\hline PS 1 & 83.0 & 12.0 & 8.0 & 33.0 & 80.0 & 17.0 & 8.0 & 6.3 \\
\hline PS 2 & 59.0 & 14.7 & 9.0 & 42.0 & 83.7 & 14.7 & 13.0 & 12.3 \\
\hline PS 3 & 53.7 & 11.0 & 11.7 & 29.7 & 62.0 & 6.0 & 15.0 & 13.0 \\
\hline Savulu samba & 100.0 & 12.0 & 7.7 & 26.3 & 102.0 & 13.3 & 6.3 & 6.0 \\
\hline White Ponni & 68.0 & 14.3 & 11.0 & 42.0 & 103.3 & 20.0 & 14.0 & 8.3 \\
\hline SE (d) & 5.0 & 0.6 & 0.5 & 2.1 & 4.9 & 0.8 & 0.7 & 0.5 \\
\hline CD 0.05 & 10.1 & 1.2 & 1.0 & 4.2 & 9.9 & 1.5 & 1.5 & 0.9 \\
\hline
\end{tabular}


Table.3 Effect of low temperature stress on growth attributes and yield of rice entries

\begin{tabular}{|c|c|c|c|c|c|}
\hline \multirow{2}{*}{ Variety } & $\begin{array}{c}\text { CGR } \\
\text { (g/m²/day) }\end{array}$ & $\begin{array}{c}\text { RGR } \\
\text { (g/g/day) }\end{array}$ & \multicolumn{2}{|c|}{$\begin{array}{c}\text { Yield per hectare } \\
(\mathrm{kg} / \mathrm{ha})\end{array}$} & \multirow{3}{*}{$\begin{array}{c}\text { Harvest } \\
\text { index }\end{array}$} \\
\hline & \multicolumn{2}{|c|}{ 0-90 DAT } & Straw yield & Grain yield & \\
\hline ADT 38 & 3.667 & 0.076 & 7187 & 4930 & \\
\hline ADT 39 & 5.320 & 0.087 & 4984 & 2972 & 37.4 \\
\hline ADT 43 & 4.206 & 0.101 & 8050 & 4329 & 35.0 \\
\hline Anna 4 & 4.456 & 0.091 & 6791 & 2961 & 30.4 \\
\hline Bhavani & 6.179 & 0.094 & 8301 & 4430 & 34.8 \\
\hline BPT 5204 & 5.593 & 0.098 & 5095 & 2416 & 32.2 \\
\hline CO 43 & 5.532 & 0.099 & 8341 & 5215 & 38.5 \\
\hline IR 20 & 5.965 & 0.098 & 7601 & 4279 & 36.0 \\
\hline DBN & 5.630 & 0.091 & 8413 & 3693 & 30.5 \\
\hline IR 50 & 3.249 & 0.090 & 6692 & 1404 & 17.3 \\
\hline K 429 & 6.117 & 0.083 & 6470 & 2984 & 31.6 \\
\hline Karuppunel & 3.640 & 0.092 & 5976 & 3196 & 34.8 \\
\hline Kottanel & 3.761 & 0.084 & 6479 & 2480 & 27.7 \\
\hline MDU 3 & 7.478 & 0.103 & 9073 & 6015 & 39.9 \\
\hline MDU 4 & 5.776 & 0.098 & 7984 & 5261 & 39.7 \\
\hline MDU 5 & 3.258 & 0.092 & 7581 & 2114 & 21.8 \\
\hline Paiyur 1 & 4.667 & 0.078 & 6273 & 2222 & 26.2 \\
\hline PS 1 & 4.851 & 0.088 & 5261 & 3236 & 38.1 \\
\hline PS 2 & 8.128 & 0.105 & 6025 & 4127 & 40.7 \\
\hline PS 3 & 2.799 & 0.082 & 6416 & 2099 & 24.7 \\
\hline Savulu samba & 4.017 & 0.094 & 7970 & 2382 & 23.0 \\
\hline White Ponni & 6.390 & 0.099 & 9502 & 3960 & 29.4 \\
\hline SE (d) & 0.386 & 0.007 & 1012 & 427 & - \\
\hline CD 0.05 & 0.780 & 0.014 & 2044 & 862 & - \\
\hline
\end{tabular}

Temperature drops to about $10^{\circ} \mathrm{C}$ during seedling establishment (October to early November) such low temperature significantly reduces seedling growth and establishment (Humphreys et al., 1996). In this present study, At 30 DAT maximum plant height $(63.0 \mathrm{~cm})$ was observed in Kottanel. Root length was maximum in BPT $5204(23.0 \mathrm{~cm})$ Maximum number of tillers (11.7) was observed in ADT 38 and was followed by IR 20 which recorded highest number of leaves per plant.

At 60 DAT, significant difference between the varieties was observed for the parameters studied. Maximum plant height $(106.0 \mathrm{~cm})$ was observed in Karuppunel. Root length was maximum in Bhavani $(20.0 \mathrm{~cm})$. Maximum 
number of tillers (16.0) was observed in IR 20 and was closely followed by Anna 4 which recorded highest number of leaves per plant. At 90 DAT, maximum plant height $(110.0 \mathrm{~cm})$ was observed in DBN. Root length was maximum in White ponni $(20.0 \mathrm{~cm})$ Maximum number of tillers (15.0) was observed in PS 3 and was closely followed by White Ponni and MDU 3 (Table 2).

The morphological adaptations with decreasing temperature are often linked to decrease in leaf area ratio (LAR), specific leaf area (SLA) and relative growth rate (RGR). Increase in leaf thickness is an adaptation mechanism to protect the photosynthetic machinery against the cold (Verheulet al., 1996). Rice genotypes having high respiratory homeostasis $(\mathrm{H})$, i.e. an ability of the plants to maintain similar respiration rates at growth temperatures, showed greater tolerance and maintained both shoot and root growth under cold conditions.

In this present study, the mean crop growth rate and relative growth rate between 0-90 DAT was the highest in the variety PS2 and was closely followed by MDU3 (Table 3).

Significant difference was observed for straw yield and grain yield among the varieties tested for low temperature stress tolerance. Straw yield was maximum in White Ponni. However maximum grain yield per hectare was recorded in the variety MDU3 and was closely followed by MDU4 and CO43 and were on par with each other. Among the twenty two varieties tested for low temperature stress tolerance, the variety
MDU3 performed better than other varieties. MDU4 and CO43 were on par with MDU3.

\section{References}

Humphreys, L., Sides, R. and Fattore, A., Rice establishment. Farmers' News letter Large Area, 147: 30-31 (1996).

Karki, S., Rizal, G. and Quick, W.P., Improvement of photosynthesis in rice (Oryza sativa $\mathrm{L}$.) by inserting the $\mathrm{C} 4$ pathway. Rice 6: $28 . \quad$ doi: 10.1186/1939-8433-6-28. pmid:24280149 (2013)

Li, H.W., Zang, B.S., Deng, X.W. and Wang, X.P., Overexpression of the trehalose6-phosphate synthase gene OsTPS1 enhances abiotic stress tolerance in rice. Planta, 234: 1007-1018 (2011).

Mackill, D.J. and Lei, X.M., Genetic variation for traits related to temperate adaptation of rice cultivars. Crop Science, 37: 1340-1346 (1997).

Mukhopadhyay, A., Vij, S. and Tyagi, A.K., Overexpression of a zinc-finger protein gene from rice confers tolerance to cold, dehydration, and salt stress in transgenic tobacco. ProcNatlAcad Sci., 101: 6309-6314 (2004).

Nishiyama, I., Physiology of Cool Weather Damage to the Rice Plant. Sapporoo, Japan, Hokkaido University Press (1985).

Verheul, M.J., Picatto, C. and Stamp, P., Growth and development of maize (Zea mays L.) seedlings under chilling conditions in the field. European Journal of Agronomy, 5: 31-43 (1996).

\section{How to cite this article:}

Anderson Amalan Kumar and Krishna Surendar, K. 2019. Physiological Basis of Screening Rice Varieties for Low Temperature Stress Tolerance. Int.J.Curr.Microbiol.App.Sci. 8(10): 905-910. doi: https://doi.org/10.20546/ijcmas.2019.810.105 